\title{
IDENTIFIKASI DRUG RELATED PROBLEM (DRP) PADA PASIEN INFEKSI SALURAN KEMIH DI RUMAH SAKIT BHAYANGKARA KENDARI
}

\author{
Musdalipah $^{1}$ \\ 1Program Studi D-III Farmasi Politeknik Bina Husada Kendari \\ *musdalipahapt@gmail.com
}

DOI : 10.24252/jkesehatan.v11i1.4908

\begin{abstract}
Abstrak
Infeksi saluran kemih (ISK) adalah suatu penyakit yang dimana terbentuknya mikroorganisme dalam jumlah banyak di saluran kemih. Dalam rangka meningkatkan penggunaan obat yang rasional, farmasis memiliki peran penting terutama dalam mengidentifikasi serta memecahkan masalah yang berkaitan dengan penggunaan obat atau Drug Related Problem (DRP) baik yang bersifat potensial maupun aktual. Tujuan penelitian ialah mengidentifikasi Drug Related Problem (DRP) pasien Infeksi Saluran Kemih (ISK) di Rumah Sakit Bhayangkara Kendari. Jenis penelitian menggunakan metode deskriptif dengan teknik pengumpulan data secara retroprospektif-prospektif berdasarkan kriteria inklusi dan eksklusi dengan melihat resep dan data rekam medik pasien. Data di analisis secara deskriptif dan dijabarkan dalam bentuk narasi. Hasil penelitian menunjukkan dari 34 pasien ditemukan Drug Related Problem (DRP) kategori adanya potensi Interaksi obat sebanyak 15 pasien (44,11\%), Polifarmasi, Interval dosis dan Efek samping obat tidak ditemukan.
\end{abstract}

Kata kunci: Drug Related Problem (DRP), ISK, Polifarmasi, Interaksi obat.

\section{Abstract}

Urinary tract infection (UTI) is a disease in which the formation of microorganisms in large quantities in the urinary tract. In order to increase rational use of drugs, pharmacists have an important role in identifying and solving problems related to Drug Related Problem (DRP), both potential and actual. The purpose of this research is to identify Drug Related Problem (DRP) of Urinary Tract Infection (ISK) patient at Bhayangkara Kendari Hospital. This research used descriptive method with retroprospective-prospective data collection technique based on inclusion and exclusion criteria by recipe and patient medical record data. The data is analyzed descriptively and described in narrative form. The results showed that 34 patients were found Drug Related Problem (DRP) category of potential drug interactions as many as 15 patients (44.11\%), Polypharmacy, dose interval and Drug side effects not found

Keywords: Drug Related Problems (DRP), ISK, Drug Interaction 


\section{PENDAHULUAN}

Dewasa ini, biaya masalah kesehatan semakin meningkat sejalan dengan perkembangan penyakit (Musdalipah dkk, 2018). Salah satunya ialah Infeksi Saluran Kemih (ISK). ISK merupakan kondisi dimana terdapat mikroorganisme dalam urin yang jumlahnya sangat banyak dan mampu menimbulkan infeksi pada saluran kemih (Dipiro et al, 2008). Infeksi Saluran Kemih memiliki prevalensi sangat bervariasi berdasarkan umur dan jelas kelamin, dimana infeksi saluran kemih lebih sering terjadi pada wanita dibandingkan dengan pria karena perbedaan anatomis antara keduanya (Rajabnia, et al, 2012).

Infeksi saluran kemih merupakan salah satu jenis infeksi nosokomial yang angka kejadiannya paling tinggi di Indonesia yaitu sekitar 39\%-60\%. Pengobatan infeksi saluran kemih sebagian besar menggunakan antibiotik. Antibiotik merupakan golongan obat yang paling banyak digunakan terkait banyaknya kejadian infeksi bakteri. Di negara berkembang $30-80 \%$ penderita yang dirawat di rumah sakit mendapat terapi antibiotik. 20 - 65\% penggunaannya dianggap tidak tepat. Penggunaan yang tidak tepat dapat menimbulkan masalah resistensi dan efek obat yang tidak dikehendaki (Lestari, et al, 2011). Tata laksana terapi ISK selain antibiotik, juga memungkinkan penggunaan obat dari golongan lain untuk meringankan gejala lain yang dapat dirasakan pasien ISK, yaitu mual, muntah, demam, disuria, dan terdesak kencing yang biasanya terjadi bersamaan disertai nyeri suprapubik dan daerah pelvis (Israr, 2009). Penggunaan lebih dari satu jenis obat dalam suatu proses terapi dapat disebut dengan polifarmasi. Polifarmasi adalah kombinasi obat yang dapat berupa kombinasi tetap dan kombinasi tidak tetap. Salah satu akibat dari polifarmasi yaitu semakin besarnya risiko interaksi obat (Tan dan Rahardja, 2007). Interaksi obat merupakan perubahan efek obat utama oleh pemberian obat lain sebelumnya atau secara bersamaan. Penggunaan antibiotik seringkali disertai dengan obat lain untuk mengatasi gejala lain atau komplikasi dari penyakit ini sehingga dapat menimbulkan interaksi antar obat. Selain itu, interaksi obat juga memiliki dampak yang berbeda-beda bila ditinjau dari tingkat keparahan interaksi sehingga perlu dimonitoring (Indira et al, 2015).

Farmasis memiliki peran penting dalam mengidentifikasi serta memecahkan masalah-masalah yang berkaitan dengan penggunaan obat atau Drug Related Problems (DRP) baik yang bersifat potensial maupun aktual. Drug Related Problem (DRP) atau masalah terkait obat adalah bagian dari asuhan kefarmasian (parmaceutical care) yang menggambarkan suatu keadaan, imana profesional kesehatan (apoteker) menilai adanya ketidaksesuaian pengobatan dalam mencapai terapi yang sesungguhnya (Musdalipah \& Nurhikma, 2017).

Hasil penelitian rasionalitas pengobatan ISK menggambarkan bahwa tepat indikasi $(96,5 \%)$, tepat obat $(66, \%)$, tepat dosis (53\%), tepat frekuensi pemberian (53\%) dan tepat durasi penggunaan antibiotik $(49,4)$ (Febrianto, et al, 2013). Rumah Sakit Bhayangkara 
Kendari memiliki pasien Infeksi Saluran Kemih sebanyak 707 pasien pada tahun 2016, dengan prevalensi yang cukup tinggi sehingga perlu dievaluasi penggunaannya untuk mencegah terjadinya DRP. Penelitian ini bertujuan mengidentifikasi DRP pasien ISK dengan kriteria polifarmasi, interaksi obat, interval dosis dan efek samping obat.

\section{METODOLOGI PENELITIAN}

\section{Rancangan Penelitian}

Penelitian dilakukan pada tahun 2017 di Rumah sakit Bhayangkara Kendari. Metode penelitian yang digunakan ialah deskriptif dengan rancangan cross sectional study pada pasien ISK (Infeksi Saluran Kemih) dengan pengambilan data secara retrospektifprospektif. Penelitian ini dilakukan berupa pengamatan terhadap peristiwa yang telah terjadi dan yang belum terjadi.

\section{Alat dan bahan}

Alat penelitian berupa lembar pengumpul data, alat tulis dan alat hitung. Bahan penelitian mencakup rekam medis pasien ISK. Rekam medis berisi data penggunaan obat pasien meliputi nama obat, dosis,frekuensi pemberian, dan efek samping obat.

\section{Populasi dan Sampel}

Populasi target penelitian ialah pasien ISK yang memenuhi kriteria inklusi (pasien rawat jalan ISK, menerima terapi obat, dan memiliki data rekam medik yang lengkap) dan kriteria eksklusi (menderita penyakit infeksi lain, usia dibawah 16 tahun dan ibu hamil). Setelah itu, dilakukan identifikasi DRP menggunakan literatur pendukung, dengan indikator polifarmasi, interval dosis, interaksi obat dan efek samping obat.

\section{Tehnik pengumpulan data}

Pengumpulan data dilakukan dengan cara observasi atau pengamatan langsung setiap kegiatan. Wawancara juga dilakukan pada pasien ISK terkait efek samping yang dikeluhkan. Data primer diperoleh melalui rekam medik pasien sedangkan data sekunder berdasarkan penelusuran jurnal dan pustaka terkait ISK.

\section{Analisis Data}

Analisis data dilakukan secara deskriptif meliputi distribusi pasien ISK berdasarkan jenis kelamin, usia, jenis obat yang digunakan dan identifikasi DRP (polifarmasi, interval dosis, interaksi obat dan efek samping obat). 


\section{HASIL DAN PEMBAHASAN}

\section{Distribusi Pasien Berdasarkan Jenis Kelamin}

Tabel 1. Distribusi Pasien Berdasarkan Jenis Kelamin pada Pasien Infeksi Saluran Kemih di Rumah Sakit Bhyangkara Kendari Tahun 2017.

\begin{tabular}{ccc}
\hline Jenis Kelamin & $\Sigma$ Pasien & Persentase $(\%)$ \\
\hline Laki-laki & 10 & 29,4 \\
\hline Perempuan & 24 & 70,6 \\
\hline Total Pasien & 34 & 100 \\
\hline
\end{tabular}

Tabel 1 menunjukkan pasien yang menderita infeksi saluran kemih didominasi jenis kelamin perempuan sebanyak 24 pasien (70,6\%) dan laki-laki sebanyak 10 pasien $(29,4 \%)$. Prevalensi dan insidensi ISK lebih banyak pada perempuan daripada laki-laki, hal ini dikarenakan faktor klinis seperti perbedaan anatomi, efek hormonal dan pola perilaku (Astal, 2009).

Infeksi saluran kemih banyak terjadi pada wanita karena uretra wanita lebih pendek sehingga bakteri kontaminan lebih mudah menuju kandung kemih dan pada usia produktif, dimana sebagian wanita sudah mulai melakukan aktivitas seksual pada usia tersebut (Coyle dan Prince, 2008).

\section{Distribusi Pasien Berdasarkan Usia}

Tabel 2. Distribusi Pasien Berdasarkan Jenis Kelamin pada Pasien Infeksi Saluran Kemih di Rumah Sakit Bhyangkara Kendari Tahun 2017.

\begin{tabular}{ccc}
\hline Usia & $\boldsymbol{\Sigma}$ Pasien & Persentase $\mathbf{( \% )}$ \\
\hline $\mathbf{1 6 - 2 5}$ & 5 & 14,7 \\
\hline $\mathbf{2 6 - 3 5}$ & 10 & 29,4 \\
\hline $\mathbf{3 6 - 4 5}$ & 8 & 23,6 \\
\hline $\mathbf{4 6 - 5 5}$ & 6 & 17,6 \\
\hline $\mathbf{5 6 - 6 5}$ & 4 & 11,8 \\
\hline $\mathbf{7 6 5}$ & 1 & 2,9 \\
\hline Total & $\mathbf{3 4}$ & $\mathbf{1 0 0}$ \\
Pasien & & \\
\hline
\end{tabular}

Tabel 2 menunjukkan angka kejadian Infeksi Saluran Kemih terbanyak pada kelompok umur 26-35 tahun sebanyak 10 pasien. Hasil penelitian menunjukkan Infeksi Saluran Kemih banyak terjadi pada usia dewasa. Aktivitas seksual yang tidak bersih seringkali menjadi penyebab masuknya bakteri kedalam saluran kemih. Penelitian ini juga mengungkap bahwa kejadian infeksi saluran kemih meningkat pada pesien 
dengan usia lebih dari 50 tahun. Hal ini disebabkan karena terjadinya kemunduran fungsi saluran kemih (Novrianti dan Reni, 2010).

3. Distribusi Jenis Obat yang Digunakan

Tabel 3. Distribusi Jenis Obat yang Digunakan Pada Pasien Infeksi Saluran Kemih di Rumah Sakit Bhayangkara Kendari Tahun 2017

\begin{tabular}{|c|c|c|}
\hline Jenis Obat & $\begin{array}{c}\text { Jumlah } \\
\text { Penggunaan }\end{array}$ & Persentase $(\%)$ \\
\hline Cefixim & 31 & 91,17 \\
\hline Kotrimoksazol & 1 & 2,94 \\
\hline Cefadroxil & 1 & 2,94 \\
\hline Ciprofloksasin & 1 & 2,94 \\
\hline \multicolumn{3}{|c|}{ AINS (n = 34) } \\
\hline Natrium Diklofenak & 22 & 64,70 \\
\hline \multicolumn{3}{|c|}{ Antipiretik $(\mathrm{n}=34)$} \\
\hline Paracetamol & 3 & 8,82 \\
\hline \multicolumn{3}{|c|}{ Antiemetik $(\mathrm{n}=34)$} \\
\hline Domperidon & 2 & 5,88 \\
\hline \multicolumn{3}{|c|}{ Obat saluran cerna $(n=34)$} \\
\hline Ranitidin & 13 & 38,23 \\
\hline Omeprazol & 5 & 14,70 \\
\hline sucralfat sirup & 3 & 8,82 \\
\hline \multicolumn{3}{|c|}{ Obat saluran kemih $(\mathrm{n}=34)$} \\
\hline Harnal OCAS & 26 & 76,47 \\
\hline \multicolumn{3}{|c|}{ Obat Wasir $(\mathrm{n}=34)$} \\
\hline Antihemoroid & 1 & 2,94 \\
\hline \multicolumn{3}{|c|}{ Obat asam urat $(n=34)$} \\
\hline Allopurinol & 1 & 2,94 \\
\hline Jumlah Pasien & 34 & \\
\hline
\end{tabular}

Tabel 3 menunjukkan jenis antibiotik yang paling banyak digunakan adalah Cefixim yaitu sebanyak 31 (91,17\%). Cefixim merupakan antibiotik dengan golongan sefalosporin yang banyak digunakan pada terapi infeksi saluran kemih karena obat tersebut merupakan drug of choice (Chisholm-Burns, et al, 2008). Siprofloksasin merupakan antibiotik yang banyak digunakan sebagai terapi pada pasien ISK. Siprofloksasin merupakan obat pilihan kedua setelah kotrimoksasol dengan resistensi E. coli $>20 \%$ pada terapi ISK. 
Siprofloksasin adalah antibiotik golongan flourokuinolon yang bekerja dengan cara menghambat kerja DNA gyrase selama proses pertumbuhan dan reproduksi bakteri. Siprofloksasin memiliki sifat bakterisid,yang berguna terutama dalam mengobati infeksi yang disebabkan oleh E. coli dan bakteri gram negatif lainnya (Mutschler E, 1999; Mycek J. M., dkk, 2001). Hasil penelitian menyebutkan bahwa penggunaan antibiotik ISK di RSUD Undata palu yaitu siprofloksasin (52,4\%), seftriakson (3,7\%), sefadroksil $(2,4 \%)$, klindamisin $(1,2 \%)$, fosfomisin $(1,2 \%)$ dan kanamisin $(1,2 \%)$ (Febrianto, et al, 2013).

Secara ideal antibiotik yang digunakan untuk mengobati infeksi diseleksi setelah organisme diidentifikasi dan sensitivitasnya terhadap obat ditetapkan (Israr, 2009). Kunci diagnosa ISK biasanya didasarkan ada gejala dan pemeriksaan adanya mikroorganisme dalam urin ( Port, C.M, and Muffin, 2009).

Pada penelitian ini sebagian besar pasien mengalami gejala mual, muntah, lemas, hilang nafsu makan, demam, berdasarkan gejala yang dialami menunjukkan bahwa pasien mengalami infeksi. Pemberian natrium diklofenak sebanyak $22(64,70 \%)$ sebagai AINS. Analgesik digunakan sebagai pengurang rasa sakit atau penghilang rasa nyeri yang merupakan gejala infeksi saluran kemih. Nyeri yang biasa dialami penderita infeksi saluran kemih adalah nyeri suprapubik (perut bawah) dan nyeri pinggang serta demam yang seringkali menyertai infeksi saluran kemih (Pratiwi, et al, 2015).

Gejala-gejala lain dari infeksi saluran kemih yaitu sering mual dan kesulitan memulai kencing, sehingga diberikan obat antiemetik seperti Domperidon (5,88\%). Pasien ISK juga mengalami gangguan pencernaan dan diberikan ranitidin $(28,23 \%)$, omeprazol $(14,70 \%)$ dan sucralfat sirup $(8,82 \%)$. Harnal OCAS $(76,47 \%)$ diberikan sebagai obat saluran kemih yang memiliki fungsi untuk melancarkan aliran urin.

\section{Identifikasi DRP}

Tabel 4 Gambaran Drug Related Problem (DRP) yang Terjadi Pada Pasien Infeksi Saluran Kemih di Rumah Sakit Bhayangkara Kendari Tahun 2017.

\begin{tabular}{clcc}
\hline No & \multicolumn{1}{c}{ DRP } & Jumlah Kejadian & Persentase (\%) \\
\hline $\mathbf{1}$ & Polifarmasi & 0 & $0 \%$ \\
\hline $\mathbf{2}$ & Potensi Interaksi obat & 15 & $44,11 \%$ \\
\hline $\mathbf{3}$ & Interval dosis & 0 & $0 \%$ \\
\hline $\mathbf{4}$ & Efek samping & 0 & $0 \%$ \\
\hline & Total Pasien & $\mathbf{3 4}$ & $\mathbf{4 4 , 1 1 \%}$ \\
\hline
\end{tabular}

Polifarmasi diklasifikasikan kedalam 2 kelas berdasarkan jumlah obat yang terdapat dalam tiap lembar resep. Polifarmasi minor adalah adalah lembar resep yang mengandung 2-4 jumlah obat, sedangkan polifarmasi mayor adalah lembar resep yang 
mengandung $=5$ jumlah obat (Reamer et al, 2008). Berdasarkan Kemenkes RI, rata-rata jumlah obat tiap pasien adalah 2, 6. Sehingga, dikatakan polifarmasi jika jumlah obat tiap pasien lebih dari 2,6 atau 3 tanpa memasukkan penyakit penyerta.

Penelitian yang telah dilakukan pada 34 pasien dengan diagnosa Infeksi Saluran Kemih di Rumah Sakit Bhayangkara Kendari tahun 2017 tidak ditemukan adanya polifarmasi (tabel 4) karena jumlah obat yang digunakan pada 34 pasien tidak melebihi 3 jumlah obat yang diterima oleh pasien untuk mengindikasi penyakit infeksi saluran kemih tanpa menambahkan item obat untuk penyakit penyerta.

\section{b. Efek Samping}

Berdasarkan wawancara yang dilakukan tidak ditemukan efek samping yang dirasakan pada pasien Infeksi Saluran Kemih di Rumah Sakit Bhayangkara Kendari (tabel 4). Efek obat bervariasi bagi setiap orang. Beberapa individu tidak merasakan efek apapun, namun ada juga yang mengalami efek samping. Variasi respon obat di antara pasien tersebut bersifat multifaktorial, termasuk faktor lingkungan, genetik, dan penyakit yang mempengaruhi disposisi (Penyerapan, distribusi, metabolisme, dan ekskresi) obat tertentu (Wilkinson, 2012).

c. Interaksi Obat

Tabel 5. Interaksi Obat Pada Pasien Infeksi Saluran Kemih di Rumah Sakit Bhayangkara Kendari tahun 2017

\begin{tabular}{lccl}
\hline Nama Obat & $\begin{array}{c}\text { Interaksi } \\
\text { Obat }\end{array}$ & Jumlah & \multicolumn{1}{c}{ Keterangan } \\
\hline Diklofenak & Ranitidin & 12 & $\begin{array}{l}\text { Diklofenak tidak mempengaruhi } \\
\text { Farmakokinetik ranitidin }\end{array}$ \\
& Sukralfat & 2 & $\begin{array}{l}\text { Sukralfat mengurangi tingkat serum } \\
\text { AUC dari diklofenak }\end{array}$ \\
\hline Ranitidin & Paracetamol & 1 & $\begin{array}{l}\text { Ranitidin mempengaruhi } \\
\text { farmakokinetik parasetamol dan } \\
\end{array}$ \\
& & & $\begin{array}{l}\text { meningkatkan nilai AUC parasetamol } \\
\text { sebesar 63\%. }\end{array}$ \\
& & &
\end{tabular}

Klasifikasi interaksi dibagi menjadi tiga kelompok yaitu interaksi minor, moderat dan mayor. Inteaksi minor adalah interaksi yang masih dalam tolerir karena jika ditemukan dalam lembar resep maka dalam terapi tidak perlukan adanya perubahan, interaksi moderat adalah interaksi yang mungkin terjadi dalam terapi dan memerlukan 
perhatian medis, sedangkan pengertian dari interaksi mayor adalah interaksi antar obat yang dapat menimbulkan konsekuensi klinis hingga kematian (Hansten, 2009).

Berdasarkan tabel 5 diperoleh obat golongan AINS yaitu diklofenak memiliki potensi berinteraksi dengan obat golongan H2 Reseptor yaitu Ranitidin dan Sukralfat. Kombinasi kedua obat ini memberikan efek terapi tambahan, obat golongan AINS memiliki efek samping pada gastrointestinal sehingga diberikan bersama obat golongan $\mathrm{H} 2$ reseptor terutama untuk pasien yang memiliki riwayat pada gastritis untuk meringankan terjadinya efek samping dari obat golongan AINS. Namun, obat-obat tersebut saling berinteraksi tetapi diklofenak tidak berpengaruh atau hanya menimbulkan efek ringan dan biasanya secara klinis tidak berpengaruh pada Ranitidin. Sedangkan Sukralfat mengurangi tingkat serum AUC dari diklofenak, namun sebagian besar bukti tersedia bahwa sukralfat tidak memiliki efek buruk pada pengobatan dengan NSAID (Stockley, 2008).

Ranitidin dan Paracetamol diberikan secara bersamaan sehingga mempengaruhi farmakokinetik parasetamol dan meningkatkan nilai AUC parasetamol sebesar $63 \%$. Namun apabila ranitidin diberikan satu jam sebelum parasetamol maka Ranitidin tidak mempengaruhi Clearance dan waktu paruh dosis tunggal paracetamol (Stockley, 2008). Interaksi obat menjadi hal yang penting untuk diperhatikan apabila secara klinis dapat meningkatkan toksisitas atau menurunkan efek terapi dari obat tersebut, hal ini dapat diperkecil potensinya degan cara menghindari penggunaan polifarmasi yang tidak dibutuhkan (Sundborn, 2012).

Potensi Interaksi obat pada penelitian ini berupa interaksi farmakokinetik sebesar 44,11\% (tabel 4). Interaksi ini digolongkan ketegori minor yang masih bisa ditolerir dengan cara menjarakkan pemberian obat. Interaksi obat walaupun harus diwaspadai karena efek yang tidak dikehendaki tetapi ada beberapa interaksi yang sengaja karena mekanisme yang sudah diketahui dan untuk mengoptimalkan efektifitas dari proses pengobatan (Agustina, et al, 2015).

\section{d. Interval Dosis}

Tabel 6. Interval Dosis Pada Pasien Infeksi Saluran Kemih di Rumah Sakit Bhayangkara Kendari Tahun 2017. 


\begin{tabular}{|c|c|c|}
\hline Nama Obat & Dosis yang diberikan & Dosis literatur \\
\hline Cefixim & $100 \mathrm{mg}$ & $\begin{array}{l}400 \mathrm{mg} / \text { hari PO dalam satu } \\
\text { dosis harian atau dibagi tiap } \\
12 \text { jam }(19,23)\end{array}$ \\
\hline Kotrimoksazol & $80 \mathrm{mg}$ & $\begin{array}{l}80 \text { mg tiap } 12 \text { jam atau } 2 \times 1 \\
\text { tablet perhari selama } 14 \text { hari } \\
(19,23)\end{array}$ \\
\hline Cefadroxil & $500 \mathrm{mg}$ & $\begin{array}{l}2 \text { gram PO tiap hari atau } \\
\text { terbagi tiap } 12 \text { jam }(18,23)\end{array}$ \\
\hline Ciprofloksasin & $500 \mathrm{mg}$ & $\begin{array}{l}500 \text { mg PO tiap } 12 \text { jam selama } \\
7-14 \text { hari }(19,23)\end{array}$ \\
\hline $\begin{array}{c}\text { Natrium } \\
\text { Diklofenak }\end{array}$ & $50 \mathrm{mg}$ & $100-150 \mathrm{mg} /$ hari $(2 \times 1){ }^{(19)}$ \\
\hline Paracetamol & $500 \mathrm{mg}$ & $\begin{array}{l}\text { 325-650 mg } 4 \text { x sehari jika } \\
\text { perlu (19) }\end{array}$ \\
\hline Domperidon & $10 \mathrm{mg}$ & $10-20 \mathrm{mg}$, 3 kali sehari ${ }^{(19)}$ \\
\hline Ranitidin & $150 \mathrm{mg}$ & $\begin{array}{l}2 \times 150 \mathrm{mg} \text { atau } 300 \mathrm{mg} \text { saat } \\
\text { mau tidur (19) }\end{array}$ \\
\hline Omeprazol & $20 \mathrm{mg}$ & $20 \mathrm{mg}-40 \mathrm{mg}$ perhari ${ }^{(19)}$ \\
\hline Sucralfat Sirup & & $4 \times 1$ gram atau $2 \times 1$ gram \\
\hline Harnal OCAS & $0,4 \mathrm{mg}$ & $\begin{array}{l}0,2-0,4 \mathrm{mg} \text { sebanyak satu kali } \\
\text { sehari (19) }\end{array}$ \\
\hline Antihemeroid & & $1 \times 1$ supp perhari ${ }^{(19)}$ \\
\hline Allupurinol & $100 \mathrm{mg}$ & Awalnya 100 mg / hari $\mathrm{PO}(19)$ \\
\hline
\end{tabular}

Pemberian interval yang tidak tepat pada terapi antibiotik dapat menyebabkan mikroorganisme (bakteri) menjadi beregenerasi menjadi lebih kuat sehingga resisten terhadap antibiotik yang diberikan (Kemenkes, 2011). Aktivitas farmakodinamik antibiotik bergantung pada konsep antibiotik time-independent vs concentrationdependent. Antibiotik kelompok $\beta$-lactam (penicillin, sefalosforin) merupakan antibiotik time-independent, artinya kerja antibiotik akan maksimal apabila interval pemberian tepat (Leekha, et al, 2011). 
Berdasarkan penelitian diperoleh hasil dosis obat yang diberikan kepada pasien ISK sudah tepat (lihat tabel 4) hal ini dibuktikan dengan membandingkan dosis terapi yang diterima pasien dengan dosis terapi berdasarkan literatur (tabel 6).

\section{KESIMPULAN}

Berdasarkan hasil penelitian disimpulkan bahwa identifikasi Drug Related Problem (DRP) dari 34 pasien ISK ditemukan adanya potensi Interaksi obat sebanyak 15 pasien $(44,11 \%)$ sedangkan polifarmasi, interval dosis dan efek samping obat tidak ditemukan.

\section{DAFTAR PUSTAKA}

Agustina., Annisa \& Prabowo. (2015) . Potensi Interaksi Obat Resep Pasien Hipertensi di Salah Satu Rumah Sakit Pemerintah di Kota Samarinda. Jurnal Sains dan Kesehatan, 1 (4) : 208 - 213.

Astal, Z. Y. E, Ciprofloxacin Resistence Among Uropathogen, in Khan A. U., (2009), Current Trends in Antibiotic Resistance in Infectious Diseases, I.K. International Publishing House, New Delhi.

Coyle, E. A. and Prince, R. A. (2008). Urinary Tract Infection and Prostatitis, in Dipiro et al., (Eds.), Pharmacotherapy : A Pathophysiologic Approach. The McGraw-Hill Companies Inc, USA.

Chisholm-Burns dkk. (2008), Pharmacotherapy principles \& practice. McGraw-Hill Medical Pub Divison.

Dipiro, J.t., Wells, (s.l). B.G., et al. Pharmacotherapy Handbook, Ninth Edition, McGrawHill Education, USA.

Febrianto., Mukaddas., \& Faustine. (2013). Rasionalitas Penggunaan Antibiotik pada Pasien Infeksi Saluran Kemih (ISK) di Instalasi Rawat Inap RSUD Undata Palu Tahun 2012. Online Journal of Natural Science, 2 (3) :20 - 29.

Hansten PD, Horn JR, (2009). Drug interactions and update. WA, Aplied Therapeutics Inc: Vancouver.

Israr, Y. A, (2009). Infeksi Saluran Kemih (ISK), Riau: Fakultas Kedokeran Universitas Negeri Riau.

Idira, Pratama, Rahmawati, Evaluasi Potensi Interaksi Obat-obat pada Pasien Rawat Inap Penderita Infeksi Saluran Kemih di RSD. dr. Soebandi Jember, Prosiding Seminar Nasional Current Challenges in Drug Use and Development : Tantangan Terkini Perkembangan Obat dan Aplikasi Klinis, , Fakultas Farmasi , Universitas Jember1 ; $2015: 56-167$. 
Lestari W., Ahmady A., Zubir N., dkk, (2011). Studi Penggunaan Antibiotik Berdasarkan Sistem ATC/DDD dan Kriteria Gysens di Bangsal Penyakit Dalam RSUP DR.M.Jamil Padang.,Tesis tidak dipublikasikan., Fakultas Farmasi, Pascasarjana, Universitas Andalas, Padang.

Leekha, S.,et al. (2011). General Principles of Antimicrobial Therapy. Mayo Clin Proc; 86(2) : $156-157$.

Mutschler E. (1999). Dinamika Obat, Farmakologi Dan Toksikologi. Institut Teknologi Bandung, Bandung.

Musdalipah dan Nurhikmah, E. (2017). Identifikasi DRPs (Drug Related Problems) Penderita ISPA Pasien Pediatrik di Instalasi Farmasi Rumah Sakit, Warta Farmasi, $6(1): 37-49$.

Musdalipah, Setiawan, M, A, Santi, E., (2018). Analisis Efektivitas Biaya Antibiotik Sefotaxime dan Gentamisin Penderita Pneumonia pada Balita di RSUD Kabupaten Bombana Provinsi Sulawesi Tenggara, Jurnal Ilmiah Ibnu Sina, 3(1) : 1 - 11.

Mycek J. M., dkk, (2001). Farmakologi Ulasan Bergambar. Widya Madika, Jakarta.

Nofriaty \& Reni (2010). Evaluasi Penggunaan Antibiotik Pada Pasien Infeksi Saluran Kemih di Instalasi Rawat Inap Rumah Sakit Umum Daerah dr. Moewardi Surakarta Tahun 2009. Surakarta: Universitas Muhammadiyah Surakarta. Naskah Tidak Dipublikasikan.

Port, C.M, and Muffin, G, Pathophisiology (2009). Concepts of Altered Health States, Lippincott Williams \& Wilkins, Philadelphia.

Pratiwi, Hening, Septimawanto D. P. (2015). Evaluasi Peresepan Antibiotik Pasien Infeksi Saluran Kemih di Instalasi Rawat Inap Rumah Sakit Roemani Semarang. Naskah tidak dipublikasi. Universitas Wahid Hasyim.

Rajabnia, M., Gooran S., Fazeli, F., Dashipour, A, (2012). Antibiotic resistance pattern in urinary tract infections in Imam-Ali hospital Zahedan 2010-2011. Zahedan Journal of Research in Medical Science: Zahedan.

Reamer LB, Massey EB, SimpsonTW, Simpson KN, (2008)., Polypharmacy: misleading, but manageable. Clinical Intervensions in Aging, 3(2) : 383- 389.

Stockley, I.H. (2008) Stockley's Drug Interaction. Pharmaceutical Press: London.

Sundborn LT, .(2012) Women and menreport deferent behaviours in and reason for medication nonadherence: a nationwide Swedish survey. Journal of Pharmacy Practice, 10(4): 207-221. 
Tan, H. T., dan Rahardja, K, (2007). Obat-Obat Penting: Khasiat, Penggunaan dan Efek-Efek Sampingnya, Jakarta: Elex Media Komputindo.

Wilkinson, Grant R., (2012). Drug Metabolism and Variability among Patients in Drug Response. University Colorado. 